\title{
Problematika Pembelajaran Daring Pendidikan Agama Islam Pada Masa Pandemi Covid-19 Di SMP Negeri 2 Sokaraja
}

\author{
Nurkholis Kurniawan, Rohmat \\ UIN Prof K.H. Saifuddin Zuhri Purwokerto \\ E-mail : nurkholiskurwn@gmail.com ${ }^{1}$,zeinrohmat2006@gmail.com²
}

\begin{abstract}
Abstrack
This research was conducted during the COVID-19 pandemic, the government issued policies such as social distancing, to large-scale social restrictions (PSSB). This condition requires people to stay at home, starting from work, worship and study at home. The government recommends carrying out the learning process from home through online learning. The sudden implementation of online learning causes various problems or problems that occur during the teaching and learning process, especially in Islamic education subjects. To find this out, the researcher formulated the problem formulation as follows: 1). How is the planning and implementation of online learning for Islamic Religious Education during the Covid-19 pandemic at SMPN 2 Sokaraja, 2). How are the evaluations and problems of online learning during the COVID19 pandemic for Islamic Religious Education subjects at SMPN 2 Sokaraja. The type of research used is descriptive qualitative research. This research was conducted through the collection of observational data, interviews and documentation. The results of the study revealed that: Learning Implementation Plans that were not in accordance with the implementation of online learning, differences in the level of understanding of students in learning lessons in online learning, students who did not have smartphones/mobile phones and limited internet quota, learning approach factors and teacher competence, teacher limitations in control the ongoing online learning as well as the lack of student motivation in learning.
\end{abstract}

Keywords: Problematics, Online Learning, Islamic Religious Education.

\begin{abstract}
Abstrak
Penelitian ini dilaksanakan pada masa pandemi COVID-19, dan pemerintah membuat sebuah kebijakan-kebijakan seperti social distancing, berupa pembatasan sosial berskala besar (PSSB). Situasi ini menuntut masyarakat untuk tetap berada didalam di rumah, mulai dari bekerja di rumah, beribadah, dan belajar. Pemerintah merekomendasikan untuk menerapkan proses belajar di rumah melalui pembelajaran online. Diterapkannya pembelajaran online secara tiba-tiba menimbulkan berbagai permasalahan atau problematika dalam proses pengajaran khususnya pelajaran Pendidikan Agama Islam. Untuk mengetahui jawabannya, peneliti merumuskan pertanyaan sebagai berikut: 1). Bagaimana merencanakan dan melaksanakan pembelajaran online untuk pendidikan agama Islam selama pandemi SMPN 2 Sokaraja, 2) Covid19. SMPN 2 Apa Mata Pelajaran Pendidikan Agama Islam Sokaraja Penilaian dan Permasalahan Pembelajaran Online Selama Pandemi COVID-19? Jenis penelitian yang dipilih yaitu penelitian kualitatif deskriptif. Penelitian dilaksanakan dengan mengumpulkan data observasi, wawancara, dan dokumen. Hasil penelitian menunjukkan bahwa rencana pelaksanaan pembelajaran tidak sejalan dengan pelaksanaan pembelajaran online. Terdapat perbedaan tingkat pemahaman pembelajaran mata kuliah antar mahasiswa dalam pembelajaran online. Siswa tanpa smartphone/HP dan keterbatasan kuota internet, metode pembelajaran dan faktor kapasitas guru, guru yang mengontrol Keterbatasan pembelajaran online yang terus menerus dan kurangnyaa motivasi para siswa untuk belajar.
\end{abstract}

Kata Kunci : Problematika, Pembelajaran Daring, Pendidikan Agama Islam. 


\section{PENDAHULUAN}

Berbicara tentang pembelajaran Pendidikan Agama Islam di masa pandemi Covid-19 ini memang sangat mengkhawatirkan. Kasus ini dimulai pada tanggal 31 Desember 2019 dari informasi Badan Kesehatan Dunia (WHO) yang menyebutkan adanya kasus yang tidak diketahui etiologinya di Wuhan, Provinsi Hubei, China. Hingga akhirnya, situasi ini terus berkembang hingga muncul laporan kematian dan impor di luar China. Pada 30 Januari 2020, WHO menyatakan Covid-19 sebagai "darurat kesehatan masyarakat untuk dunia".

Kementerian Pendidikan dan Kebudayaan akhirnya memberikan keputusan kepada siswa untuk belajar dirumah selama masa pandemi ini, namun keputusan tersebut menyebabkan berbagai pro dan kontra di masyarakat, terutama kurangnya pengetahuan teknis guru, siswa dan orang tua untuk menggunakan metode online ini. Meskipun guru harus memperkaya dan meningkatkan pengetahuannya, tidak semudah itu bagi mereka untuk segera menguasai berbagai aplikasi yang mendukung pembelajaran online. Jaringan internet yang lemah juga dianggap sebagai kendala yang sering dihadapi para guru. Apabila siswa dari latar belakang yang berbeda, siswa dari keluarga berantakan, lingkungan miskin, dan anak dari keluarga yang tidak mendukung kegiatan pendidikan, latar belakang siswa tersebut tentunya juga menjadi isu yang penting. Bagi para guru, menggunakan metode pembelajaran online ini tidak diragukan lagi merupakan tantangan yang menakutkan. Dalam pembelajaran reguler, tidak banyak dari siswa "istimewa" ini yang mau memperhatikan dan berkontribusi dalam pembelajaran, mereka sudah mau bersekolah dan sangat bersyukur. Oleh karena itu, guru harus melipatgandakan upayanya agar siswa mau mengikuti model kelas daring ini.

Pembelajaran online atau daring adalah suatu proses pembelajaran yang menggunakan internet. Di sini kita mengetahui bahwa pembelajaran dilakukan tanpa adanya tatapmuka antara guru dan siswa, sehingga guru juga harus memastikan proses belajar mengajar. Meski siswa di rumah, kegiatan tetap berjalan. Pembelajaran online atau yang biasa disebut dengan elearning adalah proses pembelajaran yang menggunakan sarana elektronik (seperti komputer, smartphone, dan lainnya).

Hal ini menyulitkan siswa dalam memahami pembelajaran agama Islam yang tidak dilakukan secara tatap muka, melainkan hanya dapat dilakukan melalui sistem pembelajaran online. Kesulitan belajar tersebut dapat berasal dari faktor eksternal atau internal, faktor internal seperti psikologi yaitu kurangnya motivasi belajar, kecerdasan, minat, dan lain-lain, dan faktor eksternal yaitu lingkungan keluarga atau lingkungan masyarakat. Hal ini sudah pasti menjadi suatu kendala yang dihadapi siswa dalam proses pembelajaran online. Dalam pembelajaran PAI sendiri, guru tidak dapat secara langsung mengontrol moral siswa atau hal lainnya karena proses pembelajarannya bersifat online (online).

Oleh karena itu, karena masalah ini, proses pembelajaran pendidikan agama Islam tidak dapat berfungsi secara optimal. Oleh karena itu, penelitian ini akan membahas pembelajaran online pendidikan agama Islam pada masa pandemi Covid19 di SMPN 2 Sokaraja. Penelitian ini diharapkan dapat membahas topik pembelajaran pendidikan agama Islam secara online di masa pandemi Covid19 secara umum.

\section{TINJAUAN PUSTAKA}

Penelitian sebelumnya telah melihat penelitian yang membahas ketidakmampuan belajar PAI. Pada penelitian ini seorang peneliti lebih memperhatikan topik pembelajaran online PAI yang tentunya berbeda dengan penelitian sebelumnya. Penyidik menunjuk ke lembaga lain, yakni SMP Negeri 2 Sokaraja.

1. SMP Negeri 6 Palangka Raya tentnag masalah pengajaran pendidikan agama Islam dalam proses pembelajaran. Penelitian ini berfokus pada perencanaan guru, tentang materi, penguasaan kelas, penggunaan dalam metode pembelajran, 
dan metode pembelajaran dalam pendidikan agama Islam (PAI). Penelitian ini yaitu penelitian kualitatif dan deskriptif dengan objek penelitian adalah guru pendidikan agama Islam, dan objek penelitiannya adalah masalah guru PAI SMP Negeri 6 Palangka Raya dalam proses pembelajaran. Hasil penelitian adalah alokasi waktu guru yang tidak konsisten antara pembuatan RPP dan alokasi waktu sekolah, serta penguasaan materi PAI yang kurang memadai, hal ini merupakan masalah internal guru. Selain itu, ketersediaan media sangat rendah, sehingga guru PAI menggunakan biaya sendiri untuk memproduksi media selain papan tulis dan buku teks. Dalam pembelajaran guru kurang mampu menciptakan suasana untuk berpartisipasi dalam pembelajaran sehingga minat siswa untuk mengikuti pembelajaran PAI menurun sehingga siswa dapat bermain lebih mandiri.

2. Masalah pembelajaran PAI di Madrasah Tsanawiyah Aceh Barat Daya. Membahas masalah yang dihadapi guru dalam proses pengajaran PAI dan mencari solusi bagi guru PAI dan madrasah untuk memecahkan masalah tersebut. Menghadapi permasalahan seperti kurangnya sarana dan prasarana pembelajaran PAI, seperti buku bacaan, minat baca siswa kurang. Metode yang digunakan guru PAI dalam proses pengajaran hanya bersifat kognitif. Solusi dari permasalahan tersebut adalah dengan merangsang semangat siswa untuk berpartisipasi aktif dalam pembelajaran, mengembangkan media pembelajaran, dan mendorong siswa untuk lebih proaktif dalam proses pembelajaran.

\section{METODE PENELITIAN}

Penelitian ini yang dipilih adalah penelitian kualitatif deskriptif. Penelitian deskriptif tidak memberikan hasil manipulasi, melainkan benar- benar memberikan informasi atau kondisi apa adanya. Tujuan dari penelitian kualitatif deskriptif yaitu untuk menjelaskan situasi atau variabel yang ada di masyarakat sebagai objek penelitian berdasarkan apa yang terjadi. Dalam penelitian ini yang dimaksud dengan deskripsi kualitatif adalah mampu menggambarkan suatu kasus secara mendalam, dan desain penelitian bersifat universal dan berubah atau berkembang sesuai dengan kondisi lokasi.

Metode penelitian yang dipilih merupakan metode penelitian deskriptif kualitatif. Metode deskriptif adalah metode yang harus menggambarkan suatu fenomena atau gejala secara sistematis, benar dan tepat. Sumber data diperoleh melalui observasi, wawancara dan pencatatan. Kemudian dianalisis melalui tiga langkah, yaitu reduksi data, penyajian data, dan terakhir penarikan kesimpulan. Dalam sebuah penelitian terdapat dua sumber data yang akan didapatkan oleh penulis, yaitu:

1) Data Primer merupakan sumber informasi dengan otoritas dan tanggung jawab pengumpulan atau penyimpanan data, juga dikenal sebagai sumber data/informasi tangan pertama. Data utama tulisan ini berasal dari siswa, guru Pendidikan Agama Islam (PAI), dan pengurus kursus tentang sistem pembelajaran online di masa pandemi COVID19.

2) Data sekunder merupakan suatu sumber informasi yang tidak memiliki kekuasaan dan tanggung jawab atas informasi yang tersedia. Data tambahan ini diperoleh dari Direktur dan Tata Usaha (TU). Data yang diperoleh dari kedua sumber ini mengacu pada sejarah berdirinya sekolah, lokasi, status konstruksi, guru, peralatan, dll..

\section{HASIL DAN PEMBAHASAN}

1. Perencanaan dan

Pembelajaran

Pelaksanaan

Agama Islam Pada Masa Pandemi COVID 19 di SMP Negeri 2 Sokaraja

a) Perencanaan pembelajaran daring PAI masa pandemi Covid-19 di SMPN 2 Sokaraja

Sebelum pembelajaran online pendidikan agama Islam, Ibu NA menyusun rencana pembelajaran dalam bentuk Rencana Pelaksanaan Pembelajaran (RPP). Rencana 
tersebut meliputi standar kecakapan dasar, indikator kinerja, tujuan pembelajaran, materi pembelajaran, metode pembelajaran, media pembelajaran, penilaian pembelajaran atau penilaian pembelajaran. Dalam hal tujuan pembelajaran, $\mathrm{Bu} \mathrm{Na}$ juga memperhatikan aspek kognisi, psikomotorik dan emosional. Perencanaan pembelajaran merupakan proses awal untuk mencapai tujuan mata kuliah secara efektif dan efisien.

Dalam contoh RPP hasil survey RPP, $\mathrm{Bu}$ NA menggunakan metode pembelajaran saintifik. Untuk model pembelajaran itu sendiri berarti menemukan pembelajaran dan menggunakan metode ceramah, diskusi, dan penyampaian. Dalam pembelajaran online seperti sekarang, Guru NA menginterpretasikan materi melalui YouTube pribadinya membuat konten yang sesuai dengan pembelajaran yang akan diajarkannya. Dalam Rencana Pelaksanaan Pembelajaran (RPP), dijelaskan bahwa sebelum membagikan materi, terlebih dahulu memulai pembelajaran dengan salam dan doa, mengecek kehadiran siswa, memberikan umpan balik dan motivasi.

Didalam RPP, bahan pembelajaran menggunakan media/alat, media proyektor LCD, komputer portabel dan AYES (PPT). Untuk menentukan model atau metode, bahkan jika sering menggunakan konferensi, diskusi dan masalah RPP, mereka disesuaikan dengan bahan yang harus disampaikan. Dalam pembelajaran online ini, Nona menjelaskan bahwa untuk pembelajaran PAI, menggunakan ruang kelas dalam variasi di media, seperti media, labirin dan dinding kata. Komunikasi dengan siswa dapat melewati ruang kelas dan WhatsApp. Deskripsi $\mathrm{Bu} \mathrm{Na}$ tidak ditunjukkan dengan jelas di PAI RPP sebelumnya.

b) Pelaksanaan pembelajaran daring PAI masa pandemi Covid-19 di SMPN 2 Sokaraja.

E-learning adalah pembelajaran yang dilakukan di Internet. Dalam jaringan semacam ini, guru dan peserta didik tidak berkomunikasi secara tatap muka. Karena pandemi Covid19, pembelajaran online saat ini sedang berlangsung. Di masa pandemi
Covid19, sistem pembelajaran online pada mata kuliah Pendidikan Agama Islam (PAI) SMP Negeri 2 Sokaraja sangat bermanfaat untuk pembelajaran melalui pemanfaatan berbagai jejaring sosial. Pembelajaran online bisa menggunakan Google Class, office 365, zoom, youtube,

atau berbagi tugas pembelajaran atau link melalui whatssApp. Saat mempelajari Pendidikan Agama Islam (PAI), kebanyakan menggunakan Google Classroom

berbagai media. Varian media ini bisa menggunakan media bukti, teaching maze, atau text walls. Selain itu, guru PAI juga memiliki akun YouTube sendiri, dan konten video pendidikan dan pembelajaran Islam yang dihasilkan akan diunggah ke YouTube agar siswa dapat menonton video dan belajar. Dengan bantuan berbagai media dan youtube, siswa tidak akan cepat bosan, berharap dapat memahami pelajaran yang diajarkan oleh guru. Prinsip pembelajaran online adalah proses pembelajaran yang berorientasi pada kegiatan pembelajaran, yang artinya guru dan siswa dapat berinteraksi dan melaksanakan proses pembelajaran online dengan baik. Sarana pembelajaran online tidak dibatasi, tetapi tetap mengacu pada prinsip-prinsip tersebut. Siswa juga dapat menggunakan media yang digunakan oleh guru, sehingga dapat terjadi pertukaran pembelajaran yang baik.

Saat mempelajari pendidikan agama Islam, guru PAI sering menggunakan Google Classroom untuk kegiatan belajar mengajar. Sebelum adanya bantuan Kemendikbud, beberapa orang tua keberatan dengan penggunaan Zoom karena dua dari 4.444 anak mereka menggunakan Zoom secara bersamaan karena menggunakan banyak pulsa atau biaya internet. Inilah sebabnya mengapa guru PAI sering menggunakan ruang kelas untuk kegiatan belajar mengajar sehari-hari. Saya menggunakan Office 365 yang direkomendasikan oleh Kementerian Pendidikan, tetapi karena masalah yang sering terjadi, saya dipandu ke ruang kelas setiap hari, karena guru dan siswa lebih nyaman dan tidak repot. Office 365 digunakan midterm/semester terakhir, karena Office 365 
dapat dikonfigurasi sebagai waktu aktivasi/deaktivasi yaitu disediakan durasi midterm/semester terakhir. Pengujian harian dapat dilakukan melalui Google Classroom.

Pembagian tugas dan materi lainnya dapat dibagikan oleh guru kepada siswa di seluruh kelas, karena setiap kelas memiliki pembagian kerja dari Kelas VII hingga Kelas IX. Dengan sistem ini, siswa dapat dengan mudah mengikuti kegiatan belajar mengajar di sekolah. Kegiatan pembelajaran online MYP SMPN 23 Surabaya juga dilaksanakan sesuai dengan jadwal mengajar sekolah biasa, bedanya waktunya dipersingkat, kalau sehari biasanya 40 menit, sekarang hanya 30 menit. Dengan cara ini, guru MYP dapat mengajar 4 atau 5 pelajaran sehari. Untuk tugas siswa bisa dikumpulkan di kelas atau di WhatsApp (WA). Setiap guru kelas memiliki grup WA, dan biasanya kepala sekolah memiliki grup WA juga, jadi jika ada kelas, tugas, atau guru lain yang ingin berkomunikasi dengan siswanya, bisa menghubungi kepala sekolah atau kepala sekolah.

\section{Evaluasi dan Problematika Pembelajaran Daring Masa Pandemi Covid-19 Mata Pelajaran PAI Bagi Peserta Didik di SMP Negeri 2 Sokaraja}

a) Evaluasi pembelajaran daring pada masa pandemi Covid-19 mata pelajaran PAI di SMP Negeri 2 Sokaraja

Evaluasi adalah proses pengecekan apakah rencana yang sedang dibangun berhasil seperti yang diharapkan semula. Evaluasi yang dapat dilakukan pada RPP sebelumnya mengacu pada tujuan pembelajaran. Tujuan pembelajaran adalah perilaku yang diharapkan siswa untuk terjadi, memiliki, atau mengontrol hasil belajar setelah mengikuti kegiatan belajar tertentu. Proses dan hasil yang ingin dicapai siswa harus sesuai dengan tujuan belajar kemampuan dasar siswa. Tujuan pembelajaran dalam RPP di atas disebutkan dalam sikap dan nilai peduli, kerja jujur, tanggung jawab, toleransi, kerjasama, dan lain-lain, berdasarkan kemampuan dasar. Selain itu, materi pembelajaran dalam RPP menyebutkan fakta, konsep, prinsip, dan prosedur dalam materi pembelajaran reguler, dan secara umum juga merujuk pada materi pembelajaran pengayaan dan materi pembelajaran remedial. Selain itu, metode dan media pembelajaran dalam RPP akan disesuaikan dengan materi yang diberikan untuk mencapai tujuan pembelajaran. Seperti menggunakan model pembelajaran penemuan (discovery learning), jika materi menjelaskan fakta, konsep, prinsip, dan prosedur, menggunakan metode ceramah, diskusi, dan distribusi. Jika materi menyebutkan jenisnya, menjelaskan arti, manfaat dan akibatnya, dapat menggunakan model pembelajaran stimulus/pencarian informasi. Hal ini sesuai dengan situasi pembelajaran online ini. Dalam pelaksanaan pembelajaran online terdapat beberapa kendala dalam menggunakan metode atau model pembelajaran seperti yang direncanakan, misalnya guru PAI sering menjelaskan materi di akun youtube, namun beberapa siswa tidak dapat memahami materi dengan baik karena interpretasi materi sering melalui youtube. video atau ruang kelas Kurangnya interaksi langsung dan komunikasi dua arah antara dosen dan guru dan siswa. Ini karena tidak ada guru yang menggunakan aplikasi zoom, dan karena beberapa orang tua keberatan dengan biaya Internet mahal yang timbul dari penggunaan aplikasi zoom.

Pelaksanaan pembelajaran online ini sama dengan pembelajaran sehari biasa di SMP Negeri 2 Sokaraja hanya saja perbedaan waktunya dipersingkat, jadi dalam keadaan normal pembelajarannya 40 menit, karena pembelajaran online ini hanya 30 menit. Pada RPP diatas dijelaskan bahwa pembelajaran $3 \times 40$ menit dalam kondisi normal, tentunya RPP tidak ada kaitannya dengan pembelajaran online saat ini. Penjelasan tentang langkahlangkah pembelajaran time-split belum digantikan oleh keadaan pembelajaran online saat ini. Mengenai media pembelajaran atau langkah pembelajaran lainnya, tidak disebutkan penggunaan media sosial dalam pembelajaran online, seperti menjelaskan konten YouTube untuk mata kuliah pendidikan agama Islam, menghubungi siswa melalui WhatsApp untuk mulai belajar atau 
menyebarkan pemberitahuan atau materi di dalam kelas.

Selama pelaksanaan pembelajaran online juga terdapat beberapa kendala pembelajaran yang membuat rencana pembelajaran tidak berhasil pada saat webinar, antara lain hambatan biaya online. Karena perbedaan ekonomi, tidak semua mahasiswa dapat rutin membeli biaya online untuk mengikuti pembelajaran online. setiap murid. Ada juga beberapa siswa yang mengalami kendala jaringan atau jaringan yang buruk, tugas yang tidak terkumpul secara maksimal, dan online yang tidak tuntas, tentunya hal ini membuat pembelajaran menjadi tidak maksimal. Menurut pernyataan Ms. NA: "Webinar terkendala biaya internet, internet tidak bagus, PR tidak terkumpul maksimal, tidak semua aktivitas online ada, jadi belajarnya kurang bagus."

Ada dua teknik penilaian untuk melaksanakan RPP. Yaitu penilaian pengetahuan dan kemampuan serta penilaian keterampilan dan kemampuan. Selain itu, ada pembelajaran remedial dan pengayaan. Dalam pembelajaran online, tes harian dilakukan di dalam kelas, dan Office 365 digunakan untuk tes tengah semester dan akhir semester yang baru. Office 365 direkomendasikan oleh Office of Education.

b) Problematika pembelajaran daring PAI pada masa pandemi Covid-19 di SMP Negeri 2 Sokaraja

Kesulitan belajar mengacu pada masalah atau hambatan yang belum terselesaikan dalam proses belajar mengajar, yang menghambat, memperumit atau menyebabkan kegagalan untuk mencapai tujuan pembelajaran. Pada pembelajaran online SMP Negeri 2 Sokaraja belum sepenuhnya berjalan karena beberapa siswa atau guru masih menghadapi beberapa kendala atau kendala. Masalah atau masalah yang dihadapi antara lain:

1) Perbedaan tingkat pemahaman peserta didik

Tingkat pemahaman siswa dalam belajar berbeda-beda, tergantung dari kemampuan siswa itu sendiri. Beberapa siswa belajar dengan cepat dengan menonton video atau sekedar membaca materi yang dapat dipahami di kelas. Namun, beberapa siswa membutuhkan waktu lama untuk memahami pelajaran. Dalam pembelajaran online ini, beberapa siswa mengalami kesulitan belajar, sehingga membutuhkan penjelasan dari orang lain. Karena guru umumnya memberikan pekerjaan rumah dan kurangnya penjelasan lebih lanjut untuk kegiatan pembelajaran tatap muka, tidak semua siswa dapat memahami mata pelajaran yang diajarkan. Karena tidak memahami siswa tersebut, mereka tidak mengerjakan pekerjaan rumah yang diberikan oleh guru.

Ngalim Purwantoa mengatakan bahwa pemahaman adalah tingkat kemampuan yang Anda inginkan untuk dapat memahami arti atau konsep, situasi, dan fakta yang Anda ketahui. Tingkat pemahaman di sini mengacu pada kemampuan siswa untuk memahami apa yang mereka pelajari, ada yang dapat memahami sepenuhnya atau sebagian memahami, dan ada yang tidak dapat menangkap makna dari materi yang dipelajari di Kadang-kadang dalam proses belajar mengajar, guru adalah pengajar utama, tetapi beberapa siswa merespons secara pasif.Ini tentu saja merupakan tantangan yang harus diatasi oleh guru.

2) Siswa yang tidak memiliki smartphone sendiri dan keterbatasan kuota internet.

Tentunya pembelajaran online membutuhkan laptop, ponsel pintar atau komputer dan sarana dan prasarana lainnya, serta bantuan internet. Jika siswa tidak memiliki smartphone, hal ini dapat menjadi penghambat pembelajaran online mereka. Dipahami bahwa beberapa siswa tidak memiliki ponsel pintar mereka sendiri, tetapi meminjam dari kerabat mereka untuk berpartisipasi dalam sistem pendidikan jarak jauh. Hal ini tentunya menjadi masalah siswa terganggu dalam kegiatan belajar mengajarnya atau tidak dapat bekerja secara normal.

Siswa yang belajar di Sokaraja mudah untuk berselancar di internet, namun bagi mahasiswa yang kurang mampu, hal ini tentunya menjadi kendala dalam pelaksanaan 
pembelajaran online karena tidak memiliki kuota akses internet yang cukup. Jika siswa tidak memiliki handphone/smartphone sendiri, maka tidak dapat memperoleh bantuan kuota internet dari Kementerian Pendidikan dan Kebudayaan. Penjelasan ini mungkin menjadi faktor eksternal kesulitan belajar siswa selama pelaksanaan pembelajaran online yang terjadi selama pandemi Covid19.

3) Faktor pendekatan pembelajaran dan kompetensi guru

Masalah pembelajaran online sendiri disebabkan oleh faktor metode pembelajaran atau kemampuan guru. Masalah yang dihadapi siswa dalam proses pengajaran mungkin karena masalah lingkungan, pola asuh, dan pendidikan. Hal ini dapat menjadi kendala atau hambatan dalam pembelajaran, sehingga bukan merupakan cara terbaik untuk mencapai tujuan pembelajaran.

Dalam pembelajaran online pendidikan agama Islam, guru kesulitan menanamkan karakter pada siswa karena kurangnya pengawasan dalam pembelajaran online. Dan ruh dari pendidikan Islam itu sendiri adalah pendidikan akhlak., Sesuai dengan tujuan pendidikan agama Islam, sekalipun peserta didik menjadi muslim sejati yang berilmu, berperilaku sesuai dengan syariat Islam, dan berakhlak mulia, karena pendidikan agama Islam sesungguhnya adalah pelajaran akhlak, yaitu mendidik pikiran dan budi pekerti, keimanan. dan takwa kepada Allah, serta bermanfaat bagi masyarakat dan agama. Oleh karena itu, pembelajaran online itu sendiri, yaitu pembelajaran yang dilakukan secara jarak jauh, atau tidak ada saksi tatap muka, dapat mengakibatkan pendidikan karakter atau benih karakter tidak dapat dikembangkan secara optimal. . Dan tidak ada jaminan bahwa siswa dapat mengikuti kursus pembelajaran online dengan serius. Dalam pembelajaran online, guru dipaksa atau diharuskan untuk belajar lebih banyak dari IT, dan hal ini terkadang kurang dikuasai oleh guru.Oleh karena itu, ketika mempersiapkan materi yang akan diajarkan, guru harus melakukan persiapan mengajar yang lebih dari biasanya. Ini seperti membuat konten
YouTube, atau mengerjakan kuis, dll agar siswa dapat dengan mudah memahami materi. Keterbatasan guru dalam mengontrol berlangsungnya pembelajaran daring.

Pembelajaran online mengacu pada pembelajaran yang tidak dilakukan secara langsung/tatap muka, melainkan melalui sistem online (online). Oleh karena itu, dalam proses pelaksanaan pembelajaran online ditemukan berbagai permasalahan atau permasalahan yang menghambat proses pembelajaran siswa. Salah satunya adalah guru memiliki kontrol yang terbatas terhadap pembelajaran online yang berkelanjutan dan tidak dapat secara langsung membantu siswa dalam belajar.

Hal ini menyulitkan siswa untuk belajar karena mereka perlu memahami mata kuliah, khususnya mata kuliah pendidikan agama Islam, dan mereka akan memahami sesuai dengan kemampuannya. Dalam keadaan ini, kegiatan belajar siswa memerlukan dukungan dan pengawasan orang tua, namun tidak semua orang tua memiliki waktu lebih untuk mengawasi kegiatan belajar anaknya karena sibuk dengan pekerjaan.

4) Kurangnya motivasi dalam belajar

Siswa bosan belajar online karena sudah lama belajar di rumah sejak pertengahan Maret 2020. Mereka juga tidak bisa bertemu langsung dengan teman atau guru, sehingga merasa malas dan bosan. Selain itu, latar belakang sosial ekonomi orang tua siswa harus bekerja, sehingga tidak dapat secara langsung mengawasi atau membantu anaknya dalam belajar. Mahasiswa dituntut untuk mandiri dalam studinya. Terkadang guru memberikan terlalu banyak pekerjaan rumah, siswa kelebihan beban, dan pekerjaan rumah tidak diserahkan tepat waktu, terlambat, atau bahkan tidak diterima. Biasanya hal ini dikarenakan banyak siswa yang menumpuk tugasnya sesuai dengan jadwal yang telah ditentukan oleh guru dan menyelesaikannya dengan cepat. Pemberian pekerjaan rumah ini tidak menjamin bahwa siswa akan belajar di rumah. Oleh karena itu, dalam proses pembelajaran online, motivasi belajar sangat diperlukan. Guru dapat memotivasi siswa sebelum mereka belajar, 
dan orang tua dapat membantu anak-anak mereka belajar meskipun mereka tidak dapat menemani mereka karena mereka sibuk dengan pekerjaan.

\section{KESIMPULAN}

Dengan pembahasan diatas tentang problematika pembelajaran daring Pendidikan Agama Islam Pada masa pandemi Covid-19 di SMP Negeri 2 Sokaraja, dapat diambil kesimpulan sebagai berikut:

a. Pembelajaran online berupa RPP masih kurang perencanaan dan belum berubah atau disesuaikan dengan pandemi Covid19. Hingga saat ini, guru dan siswa tidak dapat berinteraksi secara langsung dalam proses pengajaran. Pelaksanaan pembelajaran online PAI di SMA negeri menggunakan berbagai metode untuk mendukung proses belajar mengajar di masa pandemi Covid19. Mulailah dengan menggunakan Google Classroom dan Office 365 , membuat akun youtube, dan berkomunikasi melalui WhatsApp dan berbagai metode, seperti kuesioner, labirin, dinding teks, dll.

b. Mengevaluasi pembelajaran online dari perspektif sistem pembelajaran. Isi rencana pengajaran dan media yang digunakan dalam pembelajaran online belum diperjelas, dan lamanya waktu pembelajaran tidak diubah atau disesuaikan untuk melaksanakan pembelajaran online. Soal pembelajaran online untuk pendidikan agama Islam Selama masa pandemi Covid19 SMP Negeri 2 Sokaraja, yaitu: 1). Perbedaan tingkat pemahaman siswa, 2). siswa yang tidak memiliki handphone/smartphone sendiri dan memiliki kuota internet yang terbatas, 3). Masalah pembelajaran disebabkan oleh faktor metode pembelajaran dan kemampuan guru, 4). Keterbatasan guru untuk mengontrol pembelajaran online secara terus menerus, 5). Kurang motivasi

\section{Saran}

Berdasarkan temuan di atas, saran peneliti kepada pihak sekolah agar pihak sekolah dapat bekerjasama dengan orang tua untuk memantau siswa yang belajar di rumah agar dapat berhasil melaksanakan pembelajaran di masa pandemi Covid 19 dan dapat memberikan solusi bagi siswa yang masih menghadapi keterbatasan kuota internet. atau menggunakan smartphone selain milik siswa. Dan guru dapat memotivasi siswa untuk belajar, lebih memahami kepribadian mereka, dan melakukan pembelajaran online dengan lebih baik. Siswa juga perlu belajar keras di rumah. Guru tidak dapat secara langsung mengawasi kegiatan pembelajaran. Jika guru tidak memahami materi, ia berani bertanya kepada guru.

\section{UCAPAN TERIMA KASIH}

Terimakasih untuk semua pihak yang telah membantu terselesaikannya artikel ini terutama untuk Dr. Rohmat, M.Ag., M.Pd.

\section{DAFTAR PUSTAKA}

Anugraha, Adri. 2020. "Hambatan, solusi dan harapan: Pembelajaran Daring Selama Masa Pandemi Covid19 oleh Guru sekolah dasar". Vol. 10 No. 3, Scholaria: Jurnal Pendidikan dan Kebudayaan.

Asmuni. 2020. "Problematika Pembelajaran Daring di Masa Pandemi Covid-19 dan Solusi Pemecahannya", (Jurnal Paedagogy: Jurnal Penelitian dan Pengembangan Pendidikan, 7(4).

Efendi, Albert. 2020. Konsep Pembalajaran Daring Berbasis Pendekatan Ilmiah. Purwodadi: CV Sarnu Untung.

Hayati, Mardia. 2009. Desain Pembelajaran. Pekanbaru, Yayasan Pustaka Riau.

Lalu Gede Muhammad Zainuddin. 2020. Transformasi Media Pembelajaran Pada Masa Pandemi Covid19, (Al- Hikmah: Jurnal Studi Islam, 1(1).

Margono, S. 2003. Metodologi Penelitian Pendidikan. Jakarta: Rineka Cipta.

Mustaqim \& Wahib Abdul. 2020. Psikologi Pendidikan. Jakarta: Rineka Cipta.

Phadila, Anisa. 2020. Problematika Pelaksanaan Pembelajaran Pendidikan Agama Islam di Masa 
Pandemi Covid-19, (UINSU Jurusan Pendidikan Agama Islam.

Prawiradilaga, Dewi Salma. 2012. Wawasan Teknologi Pendidikan, (Jakarta: Kencana.

Purwanto, Ngalim. 2020. Prinsip-Prinsip dan Teknik Evaluasi Pengajaran, (Bandung: Rosda karya.

Sanjaya, Wina. 2013. Penelitian Pendidikan: Jenis, Metode, dan Prosedur. Bandung: Kencana.

Sugiyono. 2017. Metode Penelitian Kuantitatif, Kualitatif dan Kombinasi:mixed method. Bandung: Alfabeta.

Syahidin et al. 2009. Moral dan Kognisi Islam. Bandung: Alfabeta.

Yolanda, Sisca. 2020. Prpblematika Guru Dalam Pelaksanaan Kelas Daring (Online Selama Masa Pandemi Covid-19 Pada Pembelajran Tematik Siswa Kelas IV Sekolah Dasar Negeri 22/IV Kota Jambi. UIN Sulthan Taha Saifuddin Jambi. 